\title{
Breast cancer and human papillomavirus infection: No evidence of HPV etiology of breast cancer in Indian women
}

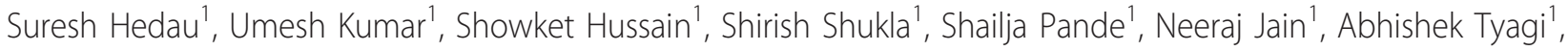 \\ Trivikram Deshpande ${ }^{3}$, Dilafroze Bhat ${ }^{4}$, Mohammad Muzaffar Mir ${ }^{5}$, Sekhar Chakraborty ${ }^{6}$, Y Mohan Singh $^{7}$, \\ Rakesh Kumar ${ }^{2}$, Kumaravel Somasundaram ${ }^{8}$, Alok C Bharti', Bhudev C Das ${ }^{1,2^{*}}$
}

\begin{abstract}
Background: Two clinically relevant high-risk HPV (HR-HPV) types 16 and 18 are etiologically associated with the development of cervical carcinoma and are also reported to be present in many other carcinomas in extra-genital organ sites. Presence of HPV has been reported in breast carcinoma which is the second most common cancer in India and is showing a fast rising trend in urban population. The two early genes E6 and E7 of HPV type 16 have been shown to immortalize breast epithelial cells in vitro, but the role of HPV infection in breast carcinogenesis is highly controversial. Present study has therefore been undertaken to analyze the prevalence of HPV infection in both breast cancer tissues and blood samples from a large number of Indian women with breast cancer from different geographic regions.

Methods: The presence of all mucosal HPVs and the most common high-risk HPV types 16 and 18 DNA was detected by two different PCR methods - (i) conventional PCR assays using consensus primers (MY09/11, or GP5 +/GP6+) or HPV16 E6/E7 primers and (ii) highly sensitive Real-Time PCR. A total of 228 biopsies and corresponding 142 blood samples collected prospectively from 252 patients from four different regions of India with significant socio-cultural, ethnic and demographic variations were tested.
\end{abstract}

Results: All biopsies and blood samples of breast cancer patients tested by PCR methods did not show positivity for HPV DNA sequences in conventional PCRs either by MY09/11 or by GP5+/GP6+/HPV16 E6/E7 primers. Further testing of these samples by real time PCR also failed to detect HPV DNA sequences.

Conclusions: Lack of detection of HPV DNA either in the tumor or in the blood DNA of breast cancer patients by both conventional and real time PCR does not support a role of genital HPV in the pathogenesis of breast cancer in Indian women.

\section{Background}

Breast cancer is the second most common cancer in the world, after the cancer of the lung, affecting one in eight women during their lifetime, but it is the leading cancer among women worldwide [1]. In India breast cancer is the second most dominant cancer in women, but it is showing a fast rising trend in major metropoli$\tan$ cities in India [2]. Although various clinico-

\footnotetext{
* Correspondence: bcdas48@hotmail.com

'Division of Molecular Oncology, Institute of Cytology \& Preventive

Oncology (ICMR), I-7, Sector - 39, Noida - 201 301, India

Full list of author information is available at the end of the article
}

epidemiologic, genetic and epigenetic factors including mutations in breast cancer susceptibility genes $B R C A 1$ and BRCA2 [3,4], sex-steroid hormones and lifestyle factors have been strongly implicated in the development of breast cancer, the mechanism(s) of breast carcinogenesis is still not clearly understood.

High-risk human papillomaviruses (HR-HPVs) are carcinogenic viruses which are primarily associated with cervical cancer but are also linked with other anogenital cancers and cancers of other organ sites [5] such as oral cavity [6-8], esophagus [9-11], nasopharyngeal and laryngeal carcinoma $[5,12-15]$ and possibly in

\section{() Biomed Central}


retinoblastoma [16-18]. In India, HPV is found to be present in $100 \%$ of cervical cancer specimens and prevalence of high risk HPV type 16 is exceptionally high ( 90\%) in them [19]. The HR-HPV oncoproteins E6 and E7 which have been found to interact and inactivate the two principal host cell tumor suppressor proteins p53 and $\mathrm{Rb}$ respectively [20-22] are also shown to immortalize human mammary epithelial cells in-vitro [23,24]. Several other viruses have also been implicated in the etiology of human breast cancer $[23,24]$ but these are not confirmed by other authors [25,26].

Reports on the distribution of HPV infection in breast cancer are not only limited but also highly controversial. Several authors [27-31] including our previous report on fine needle aspirated breast cancer cells [32] did not find any HPV infection in breast cancer. A moderate frequency of 20-48\% HPV infection was reported by many authors [33-42], whereas a very high frequency of HPV infection ranging from 60 to $85 \%$ occurrence of HPV in breast cancer was reported by others [43-46]. Most interesting is recent demonstration of high risk HPV18 in the breast cancer cell lines by in-situ hybridization and observation of HPV-specific koilocytes in breast cancer cells which reiterates the oncogenic role of HPV in breast cancer [47]. This prompted us to relook into the role of HPV in a large number of breast cancer cases that were previously analyzed for mutations in BRCA1, BRCA2 and p53 tumor suppressor genes [48] and collected from all four different regions of India. We used both conventional and real time PCR assays with consensus (MY09/11, GP5+/GP6+) and type specific (HPV16 E6/E7) primers to detect HPV DNA sequences in tumors as well as corresponding blood samples of same breast cancer patients. The results demonstrate complete absence of HPV DNA in breast cancer patients in India.

\section{Methods}

Breast cancer patient population and sample collection A total of two hundred fifty two breast cancer patients ( $\mathrm{n}=252)$ were recruited for analysis of HPV infection from different geographic regions of India. The region wise distribution of samples is presented in Table 1.
Biopsies and blood samples were collected directly from the surgical OT of respective hospitals (listed in Table 1) in chilled phosphate-buffered saline and stored at $-70^{\circ} \mathrm{C}$ till further processing. 24 blood samples of familial breast cancer cases collected (without biopsies) from Goa, a distinct geographic region of India. The majority of the cases were classified as infiltrating ductal carcinoma. Written informed consent was obtained from all the subjects included in the study and clinicoepidemiological details were taken from their clinical records. The study was approved by Institutional Ethics Committee (IEC) of all the collaborating Institutes and hospitals - Lok Nayak Hospital, New Delhi; Sher-IKashmir Institute of Medical Sciences, Srinagar, Jammu \& Kashmir; Regional Institute of Medical Science, Imphal; Assam Medical College, Dibrugarh; Silchar Medical College, Silchar; Goa Medical College, Goa and Kidwai Memorial Institute of Oncology, Bangalore in accordance with the guidelines of Indian Council of Medical Research (ICMR) and Helsinki Declaration. None of the breast cancer patients had history of any other cancer or HPV infection and all were inhabitants of India. The age of the breast cancer patients recruited varied from 25-80 years, the mean age being $51.5 \pm 16.7$.

\section{DNA extraction for PCR}

Cellular DNA from freshly collected breast tumor biopsies and peripheral venus blood were isolated using standard Proteinase $\mathrm{K}$ digestion, phenol-chloroform extraction and ethanol precipitation method routinely being used in our laboratory $[19,49,50]$. The quality and concentration of DNA was measured either on an ethidium bromide-stained 1\% agarose gel using Hind III-digested lambda marker (Figure 1A) or by standard spectrophotometric methods.

\section{Conventional PCR using L1 consensus MY09/11 and GP5 +/GP6+ or HPV16 E6/E7 primers}

Approximately, 100-200 $\eta$ g cellular DNA was utilized for conventional PCR using the protocol routinely followed in our laboratory $[48,49,51]$. For the detection of HPV DNA, both conventional as well as qRT-PCR methodology were employed using most common L1

Table 1 Distribution of breast biopsies and blood samples from the different regions of India

\begin{tabular}{|c|c|c|c|}
\hline Name of the Hospitals & Biopsies & Blood & $\begin{array}{c}\text { Matched biopsy } \\
\text { \& blood }\end{array}$ \\
\hline Lok Nayak Hospital, New Delhi & 100 & - & - \\
\hline Sher-I-Kashmir Institute of Medical Sciences, Srinagar, Jammu \& Kashmir & 43 & 43 & 43 \\
\hline Regional Institute of Medical Science, Imphal Assam Medical College, Dibrugarh Silchar Medical College, Silchar & 65 & 65 & 65 \\
\hline Goa Medical College, Goa & - & 24 & - \\
\hline Kidwai Memorial Institute of Oncology, Bangalore & 20 & 10 & 10 \\
\hline Total & 228 & 142 & 118 \\
\hline
\end{tabular}




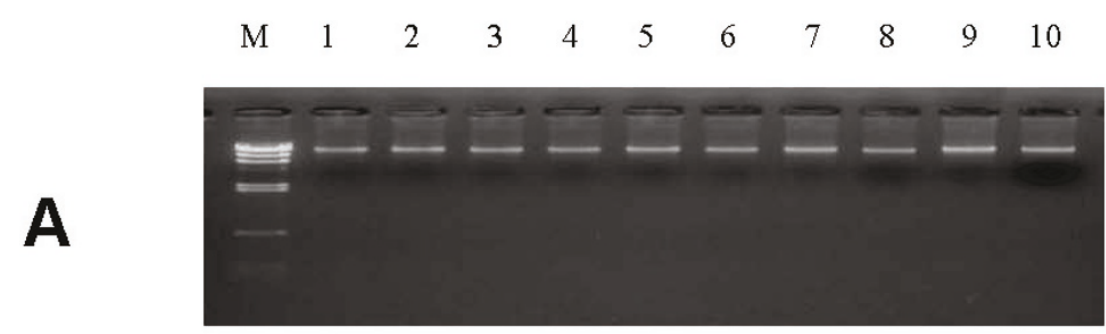

$\begin{array}{lllllllllllllllllll}M & 1 & 2 & 3 & 4 & 5 & 6 & 7 & 8 & 9 & 10 & 11 & 12 & 13 & 14 & 15 & 16 & 17 & 18\end{array}$

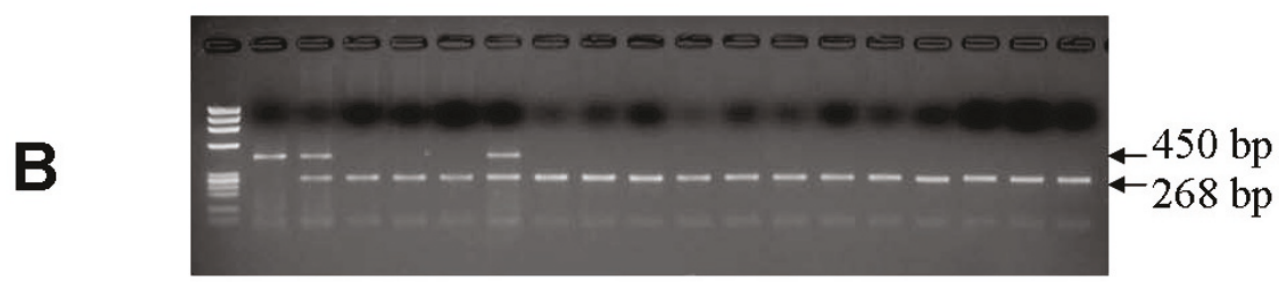

$\begin{array}{lllllllllllllllllll}M & 1 & 2 & 3 & 4 & 5 & 6 & 7 & 8 & 9 & 10 & 11 & 12 & 13 & 14 & 15 & 16 & 17 & 18\end{array}$

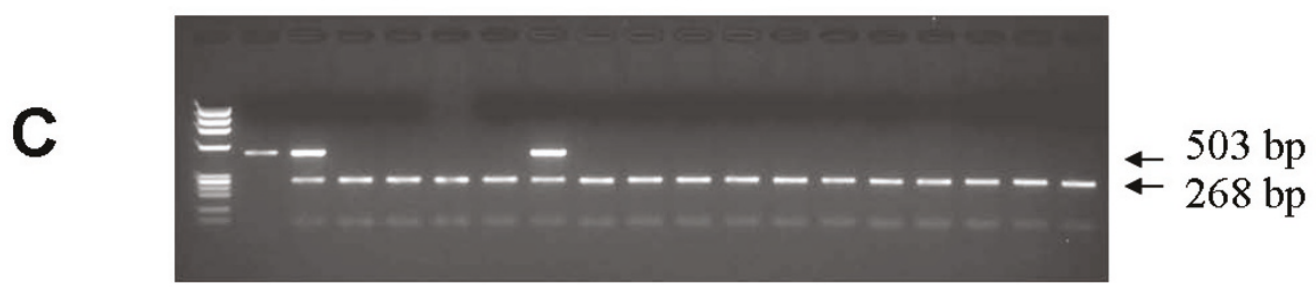

$\begin{array}{lllllllllllllllllll}\mathrm{M} & 1 & 2 & 3 & 4 & 5 & 6 & 7 & 8 & 9 & 10 & 11 & 12 & 13 & 14 & 15 & 16 & 17 & 18\end{array}$

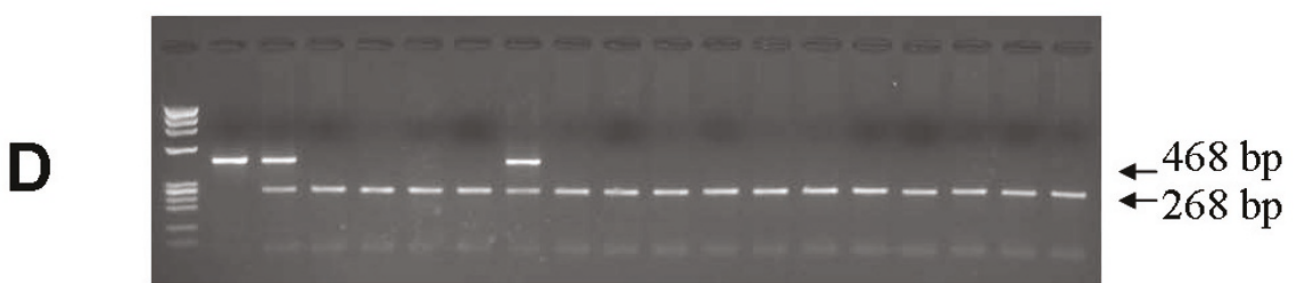

Figure 1 (A-D) Quantity and quality of genomic DNA from breast cancer biopsy and PCR amplification of different regions of HPV genome. A: Estimation of quantity and quality of phenol-chloroform extracted genomic DNA from breast cancer biopsies as visualized on an ethidium bromide-stained 1\% agarose gel. Lane M: Hind III-digested $\lambda$-DNA molecular weight marker. Lane 1-10: Genomic DNA samples from breast cancer biopsies. B: PCR amplification of HPV L-1 consensus sequences showing the amplimer of 450 bp along with $\beta$-globin of 268 bp. Lane M: Hae III-digested $\phi \times 174$ DNA molecular weight marker. Lane 1: positive control (HPV16 plasmid DNA), Lane 2: HPV16 positive cervical cancer biopsy DNA, Lane 3: Blood DNA from breast cancer patient, Lane 4: HPV negative cell line (C33a) DNA, Lane 5: MCF-7 cell DNA, Lane 6: HeLa cell DNA, Lanes 7-18: breast cancer biopsy DNA. All were positive for $\beta$-globin but none of them positive for HPV. C: PCR amplification of HPV16 E6 showing the amplimer of 503 bp along with $\beta$-globin of 268 bp. Lane M: Hae III-digested $\phi \times 174$ DNA molecular weight marker. Lane 1: positive control (HPV16 plasmid DNA), Lane 2: Cervical cancer DNA, Lane 3: Blood DNA from breast cancer patient, Lane 4: HPV negative cell line (C33a) DNA, Lane 5: MCF-7 cell DNA, Lane 6: Human placental DNA, Lane 7:SiHa cell DNA, Lanes 8-18: breast cancer biopsy DNA showing positivity for $\beta$-globin but negative for HPV. D: PCR amplification of HPV16 E7 showing the amplimer of 468 bp along with $\beta$-globin of 268 bp. Lane M: Hae III-digested $\phi \times 174$ DNA molecular weight marker. Lane 1: positive control (HPV16 plasmid DNA), Lane 2: Cervical cancer DNA, Lane 3: Blood DNA from breast cancer patient, Lane 4: HPV negative cell line (C33a) DNA, Lane 5: MCF-7 cell DNA, Lane 6: Human placental DNA, Lane 7:SiHa cell line DNA, Lane 8-18: breast cancer biopsy DNA showing positivity for $\beta$-globin but negative for HPV. 
consensus primers (MY09/11, GP5+/GP6+) or typespecific HPV16 E6/E7 primers. HPV16 plasmid DNA as well as HPV16 positive tumor DNA from cervical cancer patients or HeLa DNA served as positive controls whereas HPV negative cell line C33a DNA or human placental DNA served as negative control. Amplification of $\beta$-globin gene as well as exon 5 of p53 tumor suppressor gene served as internal controls to examine quality, integrity and successful amplification of breast tissue DNA. Sequences of consensus primers (MY09/ MY11 and GP5+/GP6+) located within the conserved L1 region of HPV genome, HPV16 E6 and E7 primers along with $\beta$-globin and p53 of exon 5 primer sequences are presented in Table- 2 .

Briefly, the method involved a $25 \mu \mathrm{l}$ reaction mix containing 100-200ๆg DNA, $10 \mathrm{mM}$ Tris- $\mathrm{Cl}$ ( $\mathrm{pH} 8.4$ ), $50 \mathrm{mM} \mathrm{KCl}, 1.5 \mathrm{mM} \mathrm{MgCl}_{2}, 12.5 \mu \mathrm{M}$ of each dNTP (dATP, dCTP, dGTP and dTTP), 5 pmoles of each oligonucleotide primer and 0.5 U Taq DNA polymerase (Perkin-Elmer Biosystems, Foster City, CA, USA). The temperature profile used for amplification constituted an initial denaturation at $95^{\circ} \mathrm{C}$ for 5 min followed by 30 cycles with denaturation at $95^{\circ} \mathrm{C}$ for $30 \mathrm{sec}$, annealing at $55^{\circ} \mathrm{C}$ for $30 \mathrm{sec}$ and extension at $72^{\circ} \mathrm{C}$ for $30 \mathrm{sec}$ which was extended for $7 \mathrm{~min}$ in the final cycle. The HPLCpurified oligonucleotide primers were custom synthesized commercially by M/s Microsynth GmbH (Balgach, Switzerland).

\section{qRT-PCR}

Highly sensitive qRT-PCR was performed for detection of low copy number HPV infection. qRT-PCR employed in the study had the capability of detecting as low as 5 copies of HPV genome per reaction which is equivalent to $0.005 \mathrm{HPV}$ copies per cell equivalent using GP5 +/GP6+ consensus primers with Biorad SYBR Green
Supermix kit and iCycler PCR (Biorad, Hercules, CA). p53 exon 5 primer sequences (Table 2) were used to normalize the HPV DNA with respect to human genomic DNA. qRT-PCR was calibrated using 10 fold serial dilutions of HPV16 International Standards (IS; ranging from $10^{4}-10^{1}$ ) supplied under WHO Global HPV LabNet program. Background genomic DNA from HPVnegative cell line C33a was used as negative control and for dilution of standards as prescribed by WHO. Briefly, the amplification was performed in $25 \mu \mathrm{l}$ reaction mix containing 5 pmol each of GP5+ and GP6+ primers and $30-50 \eta \mathrm{g}$ of genomic DNA in $5 \mathrm{ul}$ of test volume. The amplification ramp included first step for $3 \mathrm{~min}$ at $95^{\circ} \mathrm{C}$ for initial denaturation, followed by denaturation cycle of $20 \mathrm{sec}$ at $95^{\circ} \mathrm{C}$, an annealing cycle of $15 \mathrm{sec}$ at $40^{\circ} \mathrm{C}$ and an elongation and readout cycle of $30 \mathrm{sec}$ at $72^{\circ} \mathrm{C}$ for 45 cycles. The specificity was verified by a dissociation curve analysis. Linear plots of the log copy number vs the number of the threshold cycles was consistently obtained for HPV16 L1 amplification and the correlation coefficient was between 0.995 to 1.000 in each run.

\section{Results}

Of 252 patients studied, $62 \%$ were in pre-menopausal stage while the remaining $38 \%$ formed the post-menopausal group. Clinical staging showed $7.14 \%$ (18/252), $14.3 \%$ (36/252), 23.01\% (58/252), 23.8\% (60/252), 26.6\% $(67 / 252)$ and $5.15 \%(13 / 252)$ of the patients belonging to stage I, IIa, IIb, IIIa, IIIb and IV respectively, whereas histopathologic grading revealed $22.60 \%$ (57/252), 50.8\% $(128 / 252)$ and $26.6 \%(67 / 252)$ of the tumors in grade I, II and III respectively (Table 3 ). All the patients were of Indian origin and inhabitants of either New Delhi, North-East India region, southern India, Jammu \& Kashmir or Goa region. None of the patients showed family history of any other cancer. DNA isolated from

Table 2 Oligonucleotide primer sequences used for the amplification of different regions of HPV and internal control

\begin{tabular}{|c|c|c|c|c|c|}
\hline Primers & Primer Sequences & Location & $\begin{array}{l}\text { Annealing } \\
\text { temperature } \\
\left({ }^{\circ} \mathrm{C}\right)\end{array}$ & $\begin{array}{l}\text { Amplimer size } \\
\text { (bp) }\end{array}$ & Reference \\
\hline MY09 & 5'-GCM CAG GGW CAT AAY AAT GG-3' & L1 & 55 & 450 & {$[49]$} \\
\hline MY11 & $\begin{array}{l}\text { 5'-CGT CCM ARR GGA WAC TGA TC-3' where } M=A+C \\
W=A+T, Y=C+T, R=A+G)\end{array}$ & & & & \\
\hline GP5+ & 5'-TT GTT ACT GTG GTA GAT ACT AC-3' & L1 & 40 & 145 & {$[51]$} \\
\hline GP6+ & 5'-CTा ATA CTA AAT GTC AAA TAA AAA-3' & & & & \\
\hline HPV16 E6 (F) & 5'-GAA ACC GGT TAG TAT AAA AGC AGA C-3' & $53-78$ & 55 & 503 & {$[49]$} \\
\hline HPV16 E6 (R) & 5'-AGC TGG GTT TCT CTA CGT GTT CT-3' & $557-533$ & & & \\
\hline HPV16 E7 (F) & 5'-CAA TAA TAT AAG GGG TCG GTG GA-3' & $480-500$ & 55 & 468 & \\
\hline HPV16 E7 (R) & $5^{\prime}-\Pi T T$ TTC CAC TAC AGC CTC TAC AT-3' & $945-923$ & & & {$[49]$} \\
\hline$\beta$-globin (F) & 5'-GAA GAG CCA AGG ACA GGT AC-3' & $4-23$ & 55 & 268 & {$[49]$} \\
\hline$\beta$-globin (R) & 5'-CAA CTT CAT CCA CGT TAC ACC-3' & $273-256$ & & & \\
\hline p53 Exon $5(F)$ & 5'-TAC TCC CCT GCC CTC AAC AA-3' & $316-355$ & 55 & 184 & {$[48]$} \\
\hline p53 Exon $5(R)$ & 5'-CAT CGC TAT CTG AGC AGC GC-3' & $499-480$ & & & \\
\hline
\end{tabular}


Table 3 Detailed pathological classification and clinical stages of $\mathbf{2 5 2}$ breast cancer patients

\begin{tabular}{ll}
\hline Pathological classification & $\begin{array}{l}\text { Clinical } \\
\text { stages }\end{array}$ \\
\hline Infiltrating Ductal Carcinoma (IDC) (218) & Stage I (14) \\
& Stage II (83) \\
& Stage III (114) \\
& Stage IV (7)
\end{tabular}

Mixed IDC \& mucinous (20)

Stage I (4)

Stage $\|(7)$

Stage III (8)

Stage IV (1)

Medulllary Invasive carcinoma (8) Papillay invasive carcinoma (6)

Stage II (4)

Stage III (5)

Stage IV (5)

IDC; Infiltrating ductal carcinoma.

all the cases were employed for detection of HPV infection in biopsy and blood DNA using both conventional as well as highly sensitive real-time PCR methods with pre-calibrated WHO's HPV16 international standards. The tests were able to detect up to $5 \mathrm{HPV}$ genome equivalents per reaction i.e. $0.005 \mathrm{HPV}$ copies per cell equivalent. Human placental DNA or DNA derived from HPV negative C33a cells, HPV18 positive HeLa cells and DNA derived from HPV16 positive cervical cancer biopsies were used as controls.

No HPV DNA was detected using consensus primers located within the conserved L1 region of HPV genome by performing 3 to 4 times repeated conventional PCR in any of the 228 breast tumor and 142 blood DNA specimens, while $\beta$-globin showed amplification of 268 bp product in all the cases (Figure 1B). The repeat PCR of first PCR products also failed to detect any HPV DNA sequences. When these tumor DNA samples were processed for highly sensitive qRT-PCR, not a single sample was found positive for the presence of HPV DNA (Figure 2A-D). We again checked these samples with type-specific HPV16 E6/E7 primers, but all the samples were found negative for any of HPV infections (Figure 1C \&1D).

\section{Discussion}

Despite breast cancer being one of the most frequently diagnosed cancers in women, the etiology and molecular pathobiology of breast carcinogenesis is still not clearly understood. In addition to various exogenous, endogenous, hormonal and genetic risk factors responsible for breast carcinogenesis, its viral etiology particularly implicating HPV remains highly controversial. Although HPV infection, particularly the HR-HPV types 16 and 18, have been strongly implicated in the development of cervical [52] and other cancers [53-63], the evidence for an oncogenic role of HPV in breast cancer is limited.

Our previous study on a limited number of patients [32] as well as several other reports worldwide [27-31] did not observe any infection of HPV in breast cancer, whereas a moderate (20-45\%) to high frequency (60-85\%) of HPV infection has been reported by many authors [33-42]. Recent reports of detection of very high rate of $\mathrm{HPV}$ infection in breast cancer up to $85 \%$ [43-46] and in breast cancer cell lines [47] prompted us to re-look into the prevailing condition of HPV infection in breast cancer which we refuted previously [32]. Since in earlier study we used mainly fine needle aspirated (FNAC) cells from breast cancer patients $(n=26)$ including four tumor biopsy specimens to detect HPV, in the present study we have screened as many as 228 sporadic breast cancer biopsy specimens and 142 blood samples from a total of 252 breast cancer patients with no history of HPV infection or HPV-associated malignancies for the detection of HPV infection. The samples were collected from four different geographic regions of the country and two different PCR techniques both conventional and highly sensitive qRT-PCR were employed. The L1 consensus primers MY09/11 or GP5+/GP6+ and HPV16 E6/E7 (Table 2) which detect as may as 40 mucosal HPV genotypes, including the most prevalent high risk (HPV 16 \& 18) and low risk (HPV 6 \& 11) types were used but none of the samples by either methods revealed presence of HPV DNA. Additionally, blood samples from 24 familial breast cancer cases which had defined hereditary etiology for development of breast cancer failed to show presence of HPV DNA.

Of 22 previous studies on HPV in breast cancer till date, 15 reported presence of HPV infection in breast cancer and the authors have tried to put forward their possible explanation for detection of HPV DNA in breast cancer. Although the spreading of genital HPV infection from one site to the other is not established, a few studies have reported detection of genital HPVs in peripheral blood lymphocytes of patients with urinogenital cancers [64-67] and head \& neck cancers [68]. So, it has been suggested that, there is a possibility of systemic spread of oncogenic virus through organ perfusion [69] facilitating its entry into the breast through circulation. For this reason we tried to look for HPV DNA in blood samples of 142 breast cancer patients from Bangalore, North-east region, J \& K and Goa but none of them was found positive for HPV DNA. However, the detection of genital HPVs in the nipple and areolar region reported by de Villers et al. [44] suggests an alternative and perhaps more likely route of infection. Because of varied sexual behavior it is possible that genital HPVs may transmit to breast through oro-genital 


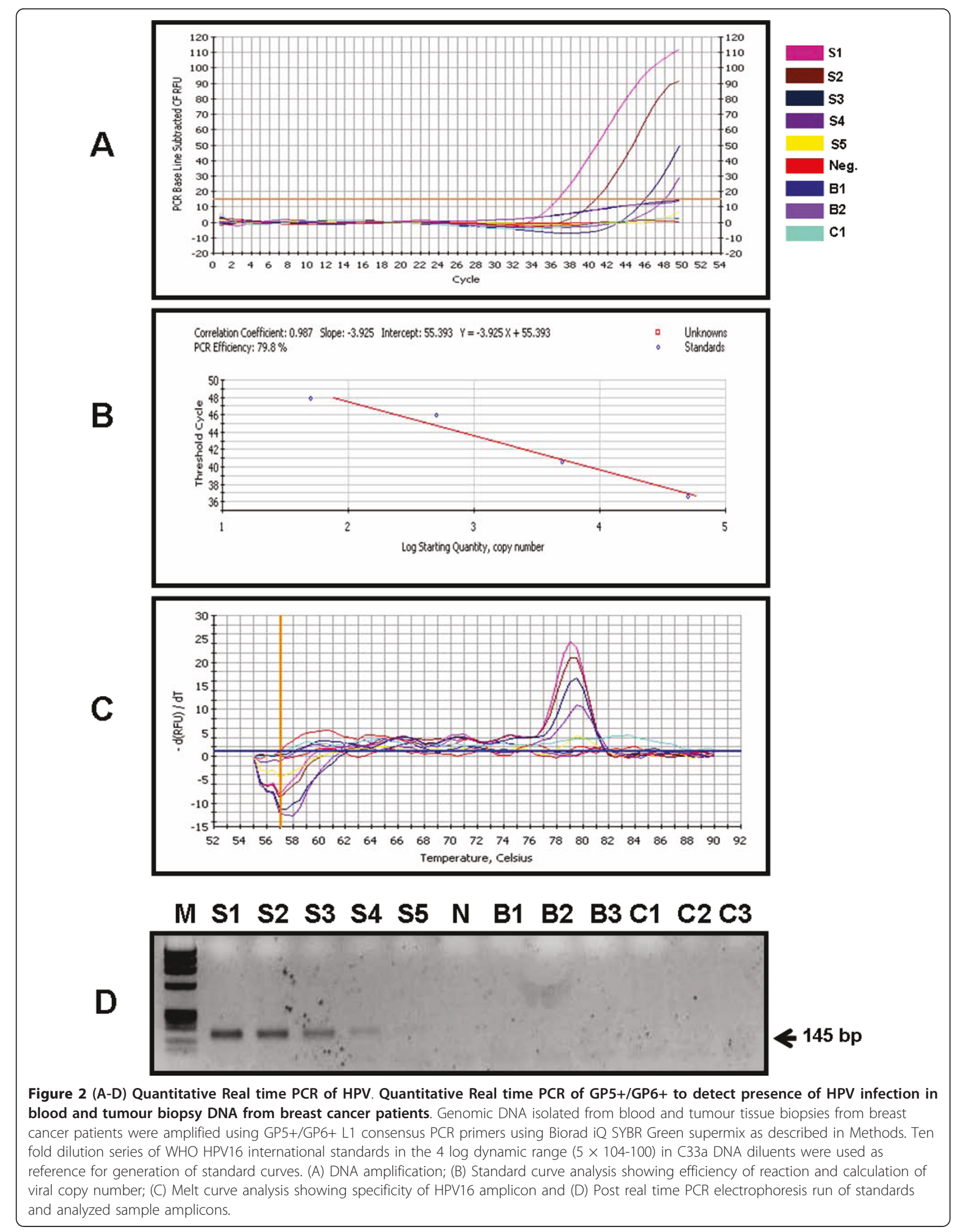


route or directly through genital-breast contacts. So there could be transmission of HPV infection by mechanical path where the virus is scrubbed through the skin [44]. However, the lack of detection of HPV in breast cancer indicates that the virus has no role to play in breast carcinogenesis in Indian women.

It is also interesting to note that several authors found both positive and negative results from the same region $[27,29,43,44]$. Studies showing positive as well as negative results for the presence of HPV infection in breast cancer and benign breast tissues are listed in Tables 4 and 5. The reports that show different results from the same country are also indicated. This could be due to variable sexual practices, composition of study subject and different HPV detection methods employed. de Villiers et al [44] reported an extremely high positivity of HPV DNA in 25 out of 29 samples (86\%) in invasive breast carcinoma and in 20 out of 29 samples (69\%) of the corresponding nipple samples collected from USA. The most prevalent HPV genotypes detected in both benign and breast tumors were HPV11 followed by HPV6 which are low risk HPV-types that generally cause benign lesions and warts and are non-oncogenic. Only $12 \%$ cases were found to have infection of high risk HPV type 16 but no HPV18 genotypes could be detected. Bratthauer et al [27], in contrast, analyzed 43 cases of breast cancer from USA for the detection of HPV DNA but surprisingly no HPV infection was observed by these authors in breast cancer cases.

Similarly, from Austria, Widschwendter et al [43] analyzed only 11 cases of breast cancer, of which 7 (63.7\%) had HPV infection while Czerwenka et al [29] from the same country reported complete absence of HPV infection in breast cancer cases. The reason(s) for disparity of presence or absence of HPV infection in breast cancer cases from the same country is not understood. It may be primarily because of selection of primer types and the amplicon region in the HPV genome which could be the possible explanation for the observed differences in HPV detection. It may also in part, be attributed to cross-contamination during collection and processing of biological samples from other organ sites, if infected with HPV.

Interestingly, in Brazilian women, Damin et al [38] could not observe HPV DNA in benign breast disease, but HPV could be detected in $25 \%$ of patients with breast carcinoma. However, HPV infection was found to have no correlation with prognosis of the disease. Lindel and her colleagues [30] showed no evidence of HPV infection in 81 Swiss women with breast carcinomas using the SPF1/2 primers covering about 40 different low, intermediate and high risk HPV types. Similarly, de Cremoux et al [31] analyzed 50 invasive breast carcinoma tissues from French patients using consensus and type-specific primers but no HPV infection were detected in any of breast cancer cases. Wrede et al [28] analyzed a group of 95 British women with breast cancer for the infection of HPV6b, 11, 13, 16, 18, 30, 31, $32,33,45$ and 51 but they also failed to detect any HPV infection. Kroupis et al [45] performed HPV test on 107 breast carcinomas in Greece and only 17 (15.9\%) were found positive. Many of them were having multiple infections of as many as 21 high risk HPV types and majority $(14 / 17 ; 67 \%)$ of them were positive for HPV16.

Table 4 List of studies identified HPV DNA sequences in breast cancer tissues

\begin{tabular}{|c|c|c|c|c|c|c|c|c|}
\hline S. No. & Study report & $\begin{array}{l}\text { Sample } \\
\text { size }\end{array}$ & $\begin{array}{l}\text { Total } \\
\text { HPV } \\
\text { positivity } \\
\text { n (\%) }\end{array}$ & $\begin{array}{l}\text { HPV16 } \\
\text { n (\%) }\end{array}$ & $\begin{array}{l}\text { HPV18 } \\
\text { n (\%) }\end{array}$ & $\begin{array}{l}\text { HPV16/18 } \\
\text { n (\%) }\end{array}$ & $\begin{array}{l}\text { Other HPV } \\
\text { types n (\%) }\end{array}$ & Country \\
\hline 1 & Di Lonardo et al., 1992 & 70 & $7(10)$ & $7(100)$ & 0 & 0 & 0 & Italy \\
\hline 2 & Henning et al., 1999 & 41 & $19(46.3)$ & $19(100)$ & 0 & 0 & 0 & Sweden \\
\hline 3. & Yu et al., 1999 & 72 & 19(26.3) & 0 & 0 & 0 & 19 (HPV 33) & China \\
\hline 4. & Yu et al., 2000 & 32 & $14(43.8)$ & 0 & 0 & 0 & 14(HPV33) & China \\
\hline 5. & Liu et al., 2004 & 17 & $6(35)$ & $3(50)$ & $1(17)$ & 0 & 0 & China \\
\hline 6. & Damin et al., 2004 & 101 & $25(24.7)$ & $14(56)$ & $10(40)$ & $1(4)$ & 0 & Brazil \\
\hline 7. & Widschwendter et al., 2004 & 11 & $7(63.7)$ & $7(100)$ & 0 & 0 & 0 & Austria* \\
\hline 8. & de Villiers et al., 2005 & 29 & $25(86.2)$ & $3(12)$ & 0 & 0 & $22(88)$ & USA* \\
\hline 9. & Kroupis et al., 2006 & 107 & $17(15.9)$ & $14(82.3)$ & 0 & 0 & $3(17.6)$ & Greece \\
\hline 10. & Kan et al., 2005 & 50 & $24(48)$ & 0 & $24(100)$ & 0 & 0 & Australia \\
\hline 11. & Gumus et al., 2006 & 50 & $37(74)$ & 0 & $20(54)$ & 0 & $35(94.6)$ & Turkey \\
\hline 12. & Khan et al., 2008 & 124 & $26(20.9)$ & $26(100)$ & 0 & 0 & 0 & Japan \\
\hline 13. & de Leon et al., 2009 & 51 & $15(29.5)$ & $10(66.7)$ & $3(20)$ & $2(13.3)$ & 0 & Mexico \\
\hline 14. & Mendizabal-Ruiz et al., 2009 & 67 & $3(4)$ & $1(33.3)$ & $1(33.3)$ & 0 & $1(33.3)$ & Mexico \\
\hline \multirow[t]{2}{*}{15.} & Heng et al., 2009 & 26 biopsies & $8(30.7)$ & $1(3.8)$ & $7(26.9)$ & 0 & 0 & Australia \\
\hline & & 9 cell lines & $2(22)$ & 0 & $2(22)$ & 0 & 0 & \\
\hline
\end{tabular}


Table 5 List of studies that did not detect HPV DNA sequences in breast cancer tissues

\begin{tabular}{|c|c|c|c|c|c|c|c|c|}
\hline S. No & Study report & $\begin{array}{l}\text { Sample } \\
\text { size }\end{array}$ & $\begin{array}{l}\text { Total HPV } \\
\text { positivity } \\
\text { n (\%) }\end{array}$ & $\begin{array}{l}\text { HPV16 } \\
\text { n (\%) }\end{array}$ & $\begin{array}{l}\text { HPV18 } \\
\text { n (\%) }\end{array}$ & $\begin{array}{l}\text { HPV16/18 } \\
\text { n (\%) }\end{array}$ & $\begin{array}{l}\text { Other HPV } \\
\text { types } \mathrm{n}(\%)\end{array}$ & Country \\
\hline 1 & Wrede et al., 1992 & 92 & 0 & 0 & 0 & 0 & 0 & UK \\
\hline 2 & Bratthauer et al., 1992 & 43 & 0 & 0 & 0 & 0 & 0 & USA* \\
\hline 3. & Gopalkrishna et al., 1996 & 30 & 0 & 0 & 0 & 0 & 0 & India \\
\hline 4. & Czerwenka et al., 1996 & 20 & 0 & 0 & 0 & 0 & 0 & Austria* \\
\hline 5. & Lindel et al., 2007 & 81 & 0 & 0 & 0 & 0 & 0 & Switzerland \\
\hline 6. & de Cremoux et al., 2008 & 50 & 0 & 0 & 0 & 0 & 0 & France \\
\hline 7. & Hedau et al. (Present study) & $252^{*}$ & 0 & 0 & 0 & 0 & 0 & India \\
\hline
\end{tabular}

* Country with both positive and negative results.

Yu et al [35] analyzed 72 patients from Shanghai, China and Tokushima in Japan found $34.1 \%$ positivity for HPV33 alone but there was no evidence of HPV16positive breast cancer. Yet another study by Mendizabal-Ruiz et al [41] analyzed 67 breast cancer patients including 40 non-malignant tissues and a very low $4.4 \%$ (3/67) frequency of HPV infection was observed. Although there exists conflicting reports, it does not insinuate that the reports that did not find viruses in breast cancer specimens were attempting to confirm or refute previous reports but failed to detect HPV. However, it is also clear from these studies that presence of HPV infection in breast cancer may not be a universal phenomenon. The prevalence of HPV infection in breast cancer may differ between places and population and several factors may contribute to this effect. This is amply clear from a recent interesting study of Heng et al [47] who analyzed HPV DNA sequences in as many as nine human breast cancer cell lines including the commonly used MCF-7 cells but only two cell lines (MDA-MB-175 VII and SK-BR-3) were found positive for HPV18. It is, however, not unlikely that these two breast cancer cell lines might have got contaminated in the laboratory with most commonly used HeLa cells that harbor HPV18.

Several other authors from different parts of the world reported presence of HPV infection in breast cancer cases. It is, however, most important to note that not many studies have indicated or analyzed if the women with breast cancer recruited for HPV detection also had anogenital or oropharynheal lesions with HPV infection. Although the route of HPV transmission from one organ to the other is not clear, Hening et al [34] demonstrated HPV16 in $46 \%$ of breast carcinoma patients who had a history of CIN III lesions. Most interestingly, all patients with HPV16 positive for breast cancer correspond to same patients with cervical CIN III lesions with HPV16 infection. This is indicative of possible transmission of virus from ano-genital organs to the breast. One of the route discussed earlier could be through blood circulation [64-68]. So, it is essential to look for genital or oropharyngeal infection of HPV in breast cancer patients to rule out the possibility of interorgan transmission and/or cross contamination of viral infection. However, published data suggest that various epidemiological factors, sexual behavior including the history of HPV-associated diseases specific to the region may play a role in differential distribution of HPV in breast cancer [30].

In spite of exceedingly higher prevalence of genital HPV infection in India as compared to that in Europe and in the USA including presence of other conducive risk factors such as early age marriage, multiple pregnancy, malnutrition, poor hygiene and healthcare, the complete absence of HPV infection in Indian women with breast cancer in the present study does not suggest the role of HPV in breast carcinogenesis in Indian women. It is suggested that although HPV DNA is undetectable, serologic assay may be useful in revealing exposure by detecting presence of antibodies against HPV. But natural HPV infection being poorly immunogenic, the antibody titer will be too low to be detected with the existing serological tests. HPV serology is presently not available in our laboratory and is being developed under the WHO LabNet programme. We however, do not preclude the possibility of yet unidentified HPV playing important role in breast carcinogenesis in India. Furthermore, due to the changing social and psyco-sexual behavior particularly in urban Indian population, it may not be unlikely to find, presence of HPV in breast tissue in future due to an exterior transfer of HPV form genital organs to the breast.

\section{Conclusions}

Complete absence of HPV DNA either in the tumor tissue or in the blood of the same breast cancer patients recruited from four different regions of the country by employing the highly sensitive qRT-PCR does not support the etiological role of oncogenic HPV in the pathogenesis of breast cancer in Indian women. 


\section{Abbreviations}

HPV: human papilloma virus; PCR: polymerase chain reaction and Breast carcinoma

\section{Acknowledgements}

We thank ICMR for financial assistance for cancer research project to Northeast regions and Department of Science and Technology (DST), Govt. of India for the project on expression and mutation of breast cancer susceptibility genes in Indian women. RK is grateful to CSIR for financial support.

\section{Author details}

'Division of Molecular Oncology, Institute of Cytology \& Preventive Oncology (ICMR), I-7, Sector - 39, Noida - 201 301, India. ${ }^{2}$ Dr. B.R. Ambedkar Centre for Biomedical Research, University of Delhi, Delhi - 110 007, India. ${ }^{3}$ Department of Zoology, Goa University, Goa - 403206, India. ${ }^{4}$ Department of Clinical Biochemistry, Sher-I-Kashmir Institute of Medical Sciences, Soura, Srinagar, Jammu and Kashmir, India. ${ }^{5}$ College of Medicine, Al-Souf University Sakaka, Kingdom of Saudi Arabia. ${ }^{6}$ Department of Pathology, Silchar Medical College, Silchar-788014, India. ${ }^{7}$ Department of Pathology, Regional Institute of Medical Science, Imphal - 795004, India. ${ }^{8}$ Department of Microbiology \& Cell Biology, Indian Institute of Science, Bangalore - 560012, India.

\section{Authors' contributions}

SH - carried out experiments, analyzed the data, and drafted the manuscript. $S$ Hussain, DB, MMM - provided breast cancer biopsy samples, clinical diagnosis and information from J \& K. UK, SP, AT, RK - to perform some of the experiments and critical reading of the manuscript. NJ, SS - has done all work related to real time PCR. TD - provided blood samples of breast cancer patients, diagnosis and clinical information from Goa. SC - provided breast cancer biopsy and blood samples, diagnosis and clinical information from Silchar. YMS - provided clinical breast cancer biopsy and blood samples, diagnosis and clinical information from Imphal. ACB - Co-designed the study and revised the manuscript. KS - collection of blood and biopsy samples from Bangalore and critical reading of the manuscript. BCD - conceived and designed the study, interpreted the data and critically corrected and communicated the manuscript. All authors have read and approved the final version of the manuscript.

\section{Competing interests}

The authors declare that they have no competing interests.

Received: 4 December 2009 Accepted: 20 January 2011 Published: 20 January 2011

\section{References}

1. Parkin DM, Bray F, Ferlay J, Pisani P: Global cancer statistics, 2002. CA Cancer J Clin 2005, 55:74-108.

2. National Cancer Registry Programme Report (Indian Council of Medical Research): 2005

3. Miki Y, Swensen J, Shattuck-Eidens D, Futreal PA, Harshman K, Tavtigian S, Liu Q, Cochran C, Bennett LM, Ding W: A strong candidate for the breast and ovarian cancer susceptibility gene BRCA1. Science 1994, 266:66-71

4. Wooster R, Bignell G, Lancaster J, Swift S, Seal S, Mangion J, Collins N, Gregory S, Gumbs C, Micklem G: Identification of the breast cancer susceptibility gene BRCA2. Nature 1995, 378:789-792.

5. Shukla S, Bharti AC, Mahata S, Hussain S, Kumar R, Hedau S, Das BC: Infection of human papillomaviruses in cancers of different human organ sites. Indian J Med Res 2009, 130:222-233.

6. Balaram P, Nalinakumari KR, Abraham E, Balan A, Hareendran NK, Bernard HU, Chan SY: Human papillomaviruses in 91 oral cancers from Indian betel quid chewers-high prevalence and multiplicity of infections. Int J Cancer 1995, 61:450-454

7. Koppikar P, deVilliers EM, Mulherkar R: Identification of human pillomaviruses in tumors of the oral cavity in an Indian community. Int $\mathrm{J}$ Cancer 2005, 113(6):946-50.

8. Mishra A, Bharti AC, Varghese P, Saluja D, Das BC: Differential expression and activation of NF-kB family proteins during oral carcinogenesis: Role of high risk human papillomavirus infection. Int J Cancer 2006, 119:2840-2850.
9. Matsha T, Erasmus R, Rafukp AB, Mugwanya D, Stepien A, Parker Ml: Human papillomavirus associated with oesophageal cancer. J Clin Pathol 2002, 55:587-590.

10. Acevedo-Nuno E, Gonzalez-Ojeda A, Vazquez-Camacho G, Balderas-Pena Luz Ma A, Moreno-Villa H, Montoya-Fuentes H: Human papillomavirus DNA and protein in tissue samples of oesophageal cancer, Barrett's oesophageal and oesophagitis. Anticancer Res 2004, 24:1319-1323.

11. Katiyar S, Hedau S, Jain N, Kar P, Khuroo MS, Mohanta J, Kumar S, Gopalkrishna V, Kumar N, Das BC: p53 gene mutation and human papillomavirus (HPV) infection in esophageal carcinoma from three different endemic geographic regions of India. Cancer Lett 2005, 218(1):69-79

12. Siddu TS, Sharma AK, Sharma N, Sen AK, Das BC: Unusual malignant transformation of juvenile recurrent respiratory papillomatosis. Otolaryngology-Head and Neck Surgery 2007, 136:321-323.

13. Wentzensen N, von Knebel Doeberitz M: Viral carcinogenesis of head and neck tumors. Pathologe 2004, 25:21-30.

14. Krishna SM, James S, Kattoor J, Balaram P: Human papillomavirus infection in Indian nasopharyneal carcinomas in relation to the histology of tumor. Indian J Pathol Microbiol 2004, 47:181-185.

15. Lopez-Lizaroaga E, Sanchez-Corona J, Montoya-Fuentes H, Bravo-Cuellar A, Campollo-Rivas O, Lopez-Demerutis E, Morgan-Villela G, ArcauteVelazquez F, Monreal-Martinez JA, Troyo R: Human papillopmavirus in tonsillar and nasopharyngeal carcinoma: isolation of HPV subtype 31. Ear Nose Throat I 2000, 79:942-944.

16. Orjuela M, Castaneda VP, Ridaura C, Lecona E, Leal C, Abramson DH, Orlow I, Gerald W, Cordon-Cardo C: Presence of human papillomavirus in tumor tissue from children with retinoblastoma: an alternative mechanism for tumor development. Clin Cancer Res 2000, 6:4010-4016.

17. Montoya-Fuentes H, de la Paz Ramirez-Munoz M, Villar-Calvo V, SuarezRinson AE, Ornelas-Aguirre JM, Vazquez-Camacho G, Orbach-Arbouys S, Bravo-Cuellar A, Sanchez-Corona J: Identification of DNA sequences and viral proteins of 6 human papillomavirus types in retinoblastoma tissue. Anticancer Res 2003, 23:2853-2862.

18. Espinoza JP, Cardenas VJ, Luna CA, Fuentes HM, Camacho GV, Carrera FM, Garcia JR: Loss of 10p material in a child with human papillomaviruspositive disseminated bilateral retinoblastoma. Cancer Genet Cytogenet 2005, 161:146-150

19. Das BC, Sharma JK, Gopalkrishna V, Das DK, Singh V, Gissmann L, zur Hausen H, Luthra UK: A high frequency of human papillomavirus DNA sequences in cervical carcinomas of Indian women as revealed by Southern blot hybridization and polymerase chain reaction. J Med Virol 1992, 36:239-245.

20. Dyson N, Howley PM, Munger K, Harlow E: The human papilloma virus-16 E7 oncoprotein is able to bind to the retinoblastoma gene product. Science 1989, 243(4893):934-7.

21. Werness BA, Levine AJ, Howley PM: Association of human papillomavirus types 16 and 18 E6 proteins with p53. Science 1990, 248(4951):76-9.

22. Scheffner M, Werness BA, Huibregtse JM, Levine AJ, Howley PM: The E6 oncoprotein encoded by human papillomavirus types 16 and 18 promotes the degradation of p53. Cell 1990, 63(6):1129-36.

23. Band V, Zaichowski D, Kulesa V, Sager R: Human papillomavirus DNA's immortalize normal epithelial cells and reduce their growth factor requirements. Proc Natl Acad Sci USA 1990, 87:463-467.

24. Wazer DE, Liu XL, Chu Q, Gao Q, Band V: Immortalization of distinct human mammary epithelial cell types by human papillomavirus 16 E6 or E7. Proc Natl Acad Sci USA 1995, 92:3687-3691.

25. Zangen R, Harden S, Cohen D, Parrella P, Sidransky D: Mouse mammary tumor-like env gene as a molecular marker for breast cancer? Int $J$ Cancer 2002, 102:304-307.

26. Witt A, Hartmann B, Marton E, Zeillinger R, Schreiber M, Kubista E: The mouse mammary tumor virus-like env gene sequences is not detectable in breast cancer tissue of Austrian patients. Oncol Rep 2003, 10:1025-1029.

27. Bratthauer GL, Tavassoli FA, O'Leary TJ: Etiology of breast carcinoma: no apparent role for papillomavirus types 6/11/16/18. Pathol Res Pract 1992, 188(3):384-6.

28. Wrede D, Luqmani YA, Coombes RC, Vousden KH: Absence of HPV16 and 18 DNA in breast cancer. Breast Cancer Research 1992, 65(6):891-4.

29. Czerwenka K, Heuss F, Hosmann JW, Manavi M, Lu Y, Jelincic D, Kubista E: Human papillomavirus DNA: a factor in the pathogenesis of mammary Paget's disease? Breast Cancer Res Treat 1996, 41:51-57. 
30. Lindel K, Forster A, Altermatt HJ, Greiner R, Gruber G: Breast cancer and human papillomavirus (HPV) infection: no evidence of a viral etiology in a group of Swiss women. Breast 2007, 16:172-177.

31. de Cremoux P, Thioux M, Lebigot I, Sigal-Zafrani B, Salmon R, SastreGarau X: No evidence of human papillomavirus DNA sequences in invasive breast carcinoma. Breast Cancer Res Treat 2008, 109:55-58.

32. Gopalkrishna V, Singh UR, Sodhani P, Sharma JK, Hedau ST, Mandal AK, Das BC: Absence of human papillomavirus DNA in breast cancer as revealed by polymerase chain reaction. Breast Cancer Res Treat 1996 39(2):197-202.

33. Di Lonardo A, Venuti A, Marcante ML: Human papillomavirus in breast cancer. Breast Cancer Res Treat 1992, 21:95-100.

34. Hennig EM, Suo Z, Thoresen S, Holm R, Kvinnsland S, Nesland JM: Human papillomavirus 16 in breast cancer of women treated for high grade cervical intraepithelial neoplasia (CIN III). Breast Cancer Res Treat 1999, 53(2):121-135.

35. Yu Y, Morimoto T, Sasa M, Okazaki K, Harada Y, Fujiwara T, Irie Y, Takahashi E, Tanigami A, Izumi K: HPV33 DNA in premalignant and malignant breast lesions in Chinese and Japanese populations. Anticancer Res 1999, 19(6B):5057-5061.

36. Yu Y, Morimoto T, Sasa M, Okazaki K, Harada Y, Fujiwara T, Irie Y, Takahashi E, Tanigami A, Izumi K: Human papillomavirus type 33 DNA in breast cancer in Chinese. Breast Cancer 2000, 7(1):33-36.

37. Liu Y, Klimberg VS, Andrews NR, Hicks CR, Peng H, Chiriva-Internati M, Henry-Tollman R, Hermonat PL: Human papillomavirus DNA is present in a subset of unselected breast cancers. J Hum Virol 2001, 4(6):329-334.

38. Damin AP, Karam R, Zettler CG, Caleffi M, Alexandre CO: Evidence for an association of human papillomavirus and breast carcinomas. Breast Cancer Res Treat 2004, 84(2):131-137.

39. Kan CY, lacopetta BJ, Lawson JS, Whitaker NJ: Identification of human papillomavirus DNA gene sequences in human breast cancer. $\mathrm{Br} J$ Cancer 2005, 93(8):946-948.

40. de Leon DC, Montiel DP, Nemcova J, Mykyskova I, Turcios E, Villavicencio V, Cetina L, Coronel A, Hes O: Human papillomavirus (HPV) in breast tumors: prevalence in a group of Mexican patients. BMC Cancer 2009, 9:26.

41. Mendizabal-Ruiz AP, Morales JA, Ramirez-Jirano LJ, Padilla-Rosas M, MoranMoguel MC, Montoya-Fuentes $\mathrm{H}$ : Low frequency of human papillomavirus DNA in breast cancer tissue. Breast Cancer Res Treat 2009, 114:189-194.

42. Khan NA, Castillo A, Koriyama C, Kijima Y, Umekita Y, Ohi Y, Higashi M, Sagara Y, Yoshinaka H, Tsuji T, Natsugoe S, Douchi T, Eizuru Y, Akiba S: Human papillomavirus detected in female breast carcinomas in Japan. Br J Cancer 2008, 99(3):408-414.

43. Widschwendter A, Brunhuber T, Wiedemair A, Mueller-Holzner E, Marth C: Detection of human papillomavirus DNA in breast cancer of patients with cervical cancer history. J Clin Virol 2004, 31(4):292-297.

44. de Villiers EM, Sandstrom RE, zur Hausen H, Buck CE: Presence of papillomavirus sequences in condylomatous lesions of the mammillae and in invasive carcinoma of the breast. Breast Cancer Res 2005, 7(1): R1-11.

45. Kroupis C, Markou A, Vourlidis N, Dionvssiou-Asteriou A, Lianidou ES: Presence of high-risk human papillomavirus sequences in breast cancer tissues and association with histopathological characteristics. Clin Biochem 2006, 39:727-731.

46. Gumus M, Yumuk PF, Salepci T, Aliustaoglu M, Dane F, Ekenel M, Basaran G, Kaya H, Barisik N, Turhal NS: HPV DNA frequency and subset analysis in human breast cancer patients normal and tumoral tissue samples. J Exp Clin Cancer Res 2006, 25(4):515-521.

47. Heng B, Glenn WK, Ye Y, Tran B, Delprado W, Lutze-Mann L, Whitaker NJ, Lawson JS: Human papilloma virus is associated with breast cancer. British Journal of Cancer 2009, 101:1345-1350.

48. Hedau S, Jain N, Husain SA, Mandal AK, Ray G, Shahid M, Kant R, Gupta V, Shukla NK, Deo SV, Das BC: Novel germline mutations in breast cancer susceptibility genes BRCA1, BRCA2 and p53 gene in breast cancer patients from India. Breast Cancer Res Treat 2004, 88:177-186.

49. Das BC, Sharma JK, Gopalkrishna V, Luthra UK: Analysis of polymerase chain reaction of the physical state of human papilloma type 16 DNA in cervical preneoplastic and neoplastic region. Journal of General Virology 1992, 73(9):2327-2336.

50. Sambrook, Russell : Molecular cloning: a laboratory manual., Third 2001, 6.6-6.11, protocol 1 .
51. de Roda Husman AM, Walboomers JM, van den Brule AJ, Meijer CJ, Snijders PJ: The use of general primers GP5 and GP6 elongated at their $3^{\prime}$ ends with adjacent highly conserved sequences improves human papillomavirus detection by PCR. J Gen Virol 1995, 76(Pt 4):1057-62.

52. zur Hausen $\mathrm{H}$ : Papillomavirus infections-a major cause of human cancers. Biochim Biophys Acta 1996, 1288(2):F55-78.

53. Pfister H, Hettich I, Runne U, Gissmann L, Chilf GN: Characterization of human papillomavirus type 13 from focal epithelial hyperplasia Heck lesions. J Virol 1983, 47:363-366.

54. de Villiers EM, Weidauer $H$, Otto $H$, zur Hausen $H$ : Papillomavirus DNA in human tongue carcinomas. Int J Cancer 1985, 36:575-578.

55. Scheurlen W, Gissmann L, Gross G, zur Hausen H: Molecular cloning of two new HPV types (HPV 37 and HPV 38) from a keratoacanthoma and a malignant melanoma. Int J Cancer 1986, 37:505-510.

56. Pfister $\mathrm{H}$ : Relationship of papillomaviruses to anogenital cancer. Obstetrics and Gynaecology Clinics of North America 1987, 14:329-469.

57. de Villiers EM: Heterogeneity of the human papillomavirus group. J Virol 1989, 63:4898-4903.

58. Backmann AM, Daling JR, Sherman KJ, Maden C, Miller BA, Coates RJ, Kiviat NB, Myerson D, Weiss NS, Hislop TG, Beagrie M, Mc Dougall JK: Human papillomavirus infection and anal cancer. Int J Cancer 1989, 43:1042-1049.

59. Perez-Ayala M, Ruiz-Cabello F, Esteban F, Concha A, Redondo M, Oliva MR, Cabrera T, Garrido F: Presence of HPV16 sequences in laryngeal carcinoma. Int J Cancer 1990, 46:8-11.

60. Snijders PJ, Steenbergen RD, Top B, Scott SD, Meijer CJ, Walboomers JM: Analysis of p53 status in tonsillar carcinomas associated with human papillomavirus. J Gen Virol 1994, 75:2769-2775.

61. zur Hausen H, de Villiers EM: Human Papillomaviruses. Annu Rev Microbiol 1994, 48:427-47

62. Heinzel PA, Balaram P, Bernard HU: Mutations and polymorphisms in the p53, p21 and p16 genes in oral carcinomas of Indian betel quid chewers. Int J Cancer 1996, 68:420-423.

63. D'Costa J, Saranath D, Dedhia P, Sanghvi V, Mehta AR: Detection of HPV-16 genome in human oral cancers and potentially malignant lesions from India. Oral Oncol 1998, 34:413-420.

64. Wei YC, Chou YS, Chu TY: Detection and typing of minimal human papillomavirus DNA in plasma. Int J Gynaecol Obstet 2007, 96:112-116.

65. Sathish N, Abraham P, Peedicayil A, Sridharan G, John S, Shaji RV, Chandy G: HPV DNA in plasma of patients with cervical carcinoma. J Clin Virol 2004, 31:204-209.

66. Dong SM, Pai SI, Rha SH, Hildesheim A, Kurman RJ, Schwartz PE, Mortel R, McGowan L, Greenberg MD, Barnes WA, Sidransky D: Detection and quantitation of human papillomavirus DNA in the plasma of patients with cervical carcinoma. Cancer Epidemiol Biomarkers Prev 2002, 11:3-6.

67. Pornthanakasem W, Shotelersuk K, Termrungruanglert W, Voravud N, Niruthisard S, Mutirangura A: Human papillomavirus DNA in plasma of patients with cervical cancer. BMC Cancer 2001, 1:2

68. Capone RB, Pai SI, Koch WM, Gillison ML, Danish HN, Westra WH, Daniel R, Shah KV, Sidransky D: Detection and quantitation of human papillomavirus (HPV) DNA in the sera of patients with HPV-associated head and neck squamous cell carcinoma. Clin Cancer Res 2000, 6:4171-4175

69. Pao CC, Lin SS, Lin CY, Maa JS, Lai CH, Hsieh TT: Identification of human papillomavirus DNA sequences in peripheral blood mononuclear cells. Am J Clin Pathol 1991, 95:540-546.

\section{Pre-publication history}

The pre-publication history for this paper can be accessed here: http://www.biomedcentral.com/1471-2407/11/27/prepub

doi:10.1186/1471-2407-11-27

Cite this article as: Hedau et al:: Breast cancer and human papillomavirus infection: No evidence of HPV etiology of breast cancer in Indian women. BMC Cancer 2011 11:27. 